\title{
Climate change perception and determinants of adoption of agricultural practices in Rasuwa district of Nepal
}

\author{
Binaya Joshi ${ }^{1^{\star}}$ and Ganesh R Joshi ${ }^{2}$
}

\begin{abstract}
${ }^{1}$ Ministry of Population and Environment, Government of Nepal ${ }^{2}$ Commission for the Investigation of Abuse of Authority, Nepal
\end{abstract}

\begin{abstract}
Climate change has become unequivocal with its implications in every aspects of life and livelhood options, including agriculture. The present paper analyzes the agrarian households' perception on climate change, identify the major agricultural practices adopted to minimize the effects of climate change and their determinants in Rasuwa district of Nepal. Nepal's agricultural production system being rain-fed in nature, the impact of climate change on productivity and production has already been experienced. During the study, the purposive sampling technique was adopted while selecting the VDCs located within the buffer zone of Langtang National Park. Four VDCs namely Laharepauwa, Dhaibung, Dhunche and Syaphru were purposively selected representing paddy, wheat, maize, and potato production area of the district. Thirty households from each VDC were interviewed by using the structured questionnaire totaling a sample size of 120 households. In addition, the present study also used Focus Group Discussions with local government officials, buffer zone communities and other stakeholders about the climate change knowledge and adaptation, and to assess perception on different climate change related threats and strategies adapted to cope the impact. Information with regard to the experience of the respondent in cultivating the crop in question, changes in rainfall amount and time, seasonal change in temperature and their effect on the time of planting and yield, and the adaptation strategy were collected. The factors influencing whether to adopt climate adaptation practices in agriculture was analyzed using binary logit model. The education level of household head, household size, food self-sufficiency from their own production and inadequacy of current knowledge on agricultural adaptation influenced the adoption. In the Nepalese context, where agricultural occupation is the dominant means of living, climate adaptation seems to be the most efficient and friendly way for farmers to neutralize the potential adverse effects. The farmer's knowledge and skills on techniques of adaptation need to be enhanced and support in availing such practices and technologies which may result for better adoption. The awareness raising campaigns need to be organized and indigenous knowledge and practices should be documented and verified for further replication.
\end{abstract}

Key words: Adoption, Agricultural productivity, Climate change, Rasuwa, Nepal

\section{Introduction}

The average temperature increase at the global level has been $0.6^{\circ} \mathrm{C}$ during the $20^{\text {th }}$ century. The 1990 s was the warmest decade and 1998 the warmest year in the instrumental record, since 1861 (IPCC, 2001). Natural and human systems are expected to be exposed to direct effects of climatic variations such as changes in temperature and precipitation variability, as well as frequency and magnitude of extreme weather events. The previous studies show that some low-lying developing countries and small island states are expected to face very severe impacts that could have associated damage and huge adaptation costs. Climate change impacts are expected to exacerbate poverty in most developing countries and create new poverty pockets in countries with increasing inequality, in the both developed and developing countries (IPCC, 2014).

*Corresponding author, email address: joshibinaya84@gmail.com
Because of high dependence on the agricultural sector, loss of agricultural productivity due to climate change significantly affects the economy of many developing countries (Gebreegziabher et al., 2011). Increase in temperature results in a reduced growing season and a decline in productivity, particularly in South Asia (Pachauri, 1992). A warming climate would increase water demand on the one hand and would decrease river flows on the other. In case of Nepal, there will be change in the spatial and temporal distribution of temperature and precipitation due to climate change, which in turn will increase both the intensity and frequency of extreme events lik e droughts and floods (Mahtab, 1992).

The climate change and its impacts have already been experienced in Nepal. Temperature trend analysis in Nepal, using data from 
1977 to 1994 indicates, a consistent and continuous war ming during the period at an annual rate of $0.06^{\circ} \mathrm{C}(\mathrm{MoE}, 2010)$. A similar study conducted by Practical Action (2009), looking at data from 45 weather stations for the period 1976-2005, indicated a consistent and continuous warming of maximum temperatures at an annual rate of $0.04{ }^{\circ} \mathrm{C}$. These studies also indicate that the obser ved warming trend in the country is spatially variable.

About two-third of the economically active population of Nepal depend on agriculture for their livelihood and this sector contributes about one-third of gross domestic product. But, most of the farming in Nepal is rain-fed. All the crop-water requirements of the non-irrigated lands are met solely by rainfall. The increased precipitation variability may create difficulties in cultivating these lands and could result in probable food insecurity for the growing population. Moreover, the agricultural land cur rently having irrigation facilities may not have sufficient water during dry seasons in the future due to climate change. This may result in water stress in the agricultural sector of Nepal. The poor people are more vulnerable to climatic extremes as well as gradual changes in climate than the rich as they have less protection, less reser ves, fewer alternatives and a lower adaptive capacity and are more reliant on primary production (IPCC, 2001; AfDB et al., 2003).

Climate change may alter rainfall and snowfall patter ns. The incidence of extreme weather events such as droughts, stor ms, floods and avalanches is expected to increase. This can lead to loss of lives and severely reduce agricultural production (IPCC, 1998). Traditional wisdom and knowledge to cope with such natural hazards that once ensured food security may no longer prove effective (Jenny \& Egal, 2002). Climate-induced natural hazards have very serious human implications because they affect the livelihood security of the majority of the population (Swaminathan, 2002). About 29\% of the total annual deaths of people and $43 \%$ of the total loss of properties from all different disasters in Nepal are caused by waterinduced disasters like floods, landslides and avalanches (Khanal, 2005).

The higher temperatures also increase the process of evapotranspiration and decreases soil moisture availability. As global warming is likely to increase rainfall, the net impact of higher temperatures on water availability is a race between higher evapotranspiration and higher precipitation. As the precipitation is not regular, the race will be won by higher evapotranspiration (Cline, 2008). Rain-fed agriculture is likely to be affected adversely by the climate change.

In one hand, higher concentration of $\mathrm{CO}_{2}$ and carbon fertilization increases plant photosynthesis, and thus crop yields (Kimball, 1983; Rosenzweig \& Hillel, 1998). Enhanced photosynthesis can increase the yield of $\mathrm{C} 3$ crops such as wheat, rice and soybeans, but not of the C4 crops such as sugarcane and maize (Cline, 2008).
On the other hand, increase in the temperature and changes in precipitation pattern have potential to affect crop yields either positively or negatively (Reilly et al., 2001). Chang (2002) has estimated crop yield response models and founds the negative effects associated with some climate changes. Physical effects of temperature rise on crop yield are feared more damaging in tropical and subtropical countries than in the temperate countries.

Appropriate adaptation to changing climatic conditions improves society's ability to cope with the impact of change. In a r ural community, where agricultural activity is the dominant means of living, adaptive capacity enables farming system to adjust to climate change (including climate variability and extremes), to moderate potential damages, to take advantage of the opportunities, or to cope with the consequences. In community 's life, the ultimate goal of an adaptation measure is to increase the capacity of a farming system to survive external shocks or change (Tesso et al. 2012). The assessment of far m-level adaptation strategies is important in providing information that can be used to formulate policies and design programs which enhance effectiveness in reducing risks from climate change in agriculture. In this context, the present study has analyzed the agrarian households' perception on climate change; identified the major agricultural adaptation practices and techniques to climate change and their determinants of adoption in Rasuwa district of Nepal.

\section{Materials and Methods Description of the study area}

Langtang is one of the most unspoiled national parks of Nepal, situated north of $\mathrm{K}$ athmandu. It is the most easily accessible highland sanctuary from the capital. Rasuwa district is one of the mountain districts of Nepal. The district is situated at $120 \mathrm{~km}$ north of Kathmandu with total area $1544 \mathrm{~km}^{2}$. The district's altitude ranges from $845 \mathrm{~m}$ to $7245 \mathrm{~m}$ from mean sea level. The climatic conditions are characterized by warm and moist summer, coinciding with the monsoon season (June-September); relatively warm and sunny autumn and spring seasons; and cold winter with occasional snowfalls (coldest months being January and February). Altitudinal and topographic variation, however, produces considerable local variations in climatic conditions in this district. Among the inhabitants, the majority of the groups is dominated by Tamangs (68.8\%) followed by Brahmins (15.1\%), Gurungs (3.1\%), Chhetri (2.5\%) and others (10.5\%) (CBS, 2014). Rasuwa is rich equally in natural and cultural resources. Tourism is the second most viable economic sector after agriculture (DDC-R, 2002). The Dhunche and Syaphru VDCs are inhabited mostly by Tamangs (75\%) and Brahmins is a dominant ethnic group (46\%) in Daibung and Laharepauwa VDCs. The number of people living below the poverty line income (Rs 19261 per capita per year) in this district reached $31.6 \%$ of the population, which is higher than the national average, $25.2 \%$ (CBS, 2011b).

\section{新 TU-CDES}




\section{Data source and sample size}

The study used cross-sectional survey data from 120 households collected during 2009. Data were collected through questionnaire survey and, focus group discussions (FGDs). Both str uctured questionnaire and interviews were held with local gover nment officials, buffer zone communities and all other stakeholders on climate change knowledge and adaptation. In addition, the study also used Focus Group Discussions to assess perception on different climate change related threats and strategies adapted to cope with the impact of climate change.

Being an explorator y type of study, the purposive sampling technique was adopted, while selecting the VDCs situated within the buffer zone of Langtang National Park. In order to meet the study objective, four VDCs were purposively selected representing paddy, wheat, maize, and potato production area of the district. A two stage sampling technique was adopted to select the respondent households. In the first stage, a ward was randomly selected. In the second and final stage, the households cultivating the crop in question were selected from the list. Thirty households from each VDC were inter viewed by using the str uctured questionnaire, totaling a sample size of 120 households. The information with regard to the experience of the respondent in cultivating the crop in question, changes in rainfall amount and time, seasonal change in temperature and their effect on the time of planting and yield and the adaptation strategy, if any, were collected. One VDC was from the upper area (such as Syaphru), another one was from the middle such as Dhunche and further two were from the lower zones (Daibung and L aharepauwa) (Fig. 1). For analyzing the climatic trend, the data on temperature and precipitation for Dhunche were obtained from Department of Hydrology and Meteorology for the year 1989 to 2012.

\section{Empirical model}

The adoption of agricultural technologies and climte change adaptation practices involve decisions on whether to adopt such technologies and practices, or not. Previous studies have observed that agricultural technology adoption models are based on famers' utility or profit maximizing behaviors (Norris \& Batie, 1987). Binary logit or probit models are employed when the number of choices available are limited only at two cases. In this study, a binary logistic

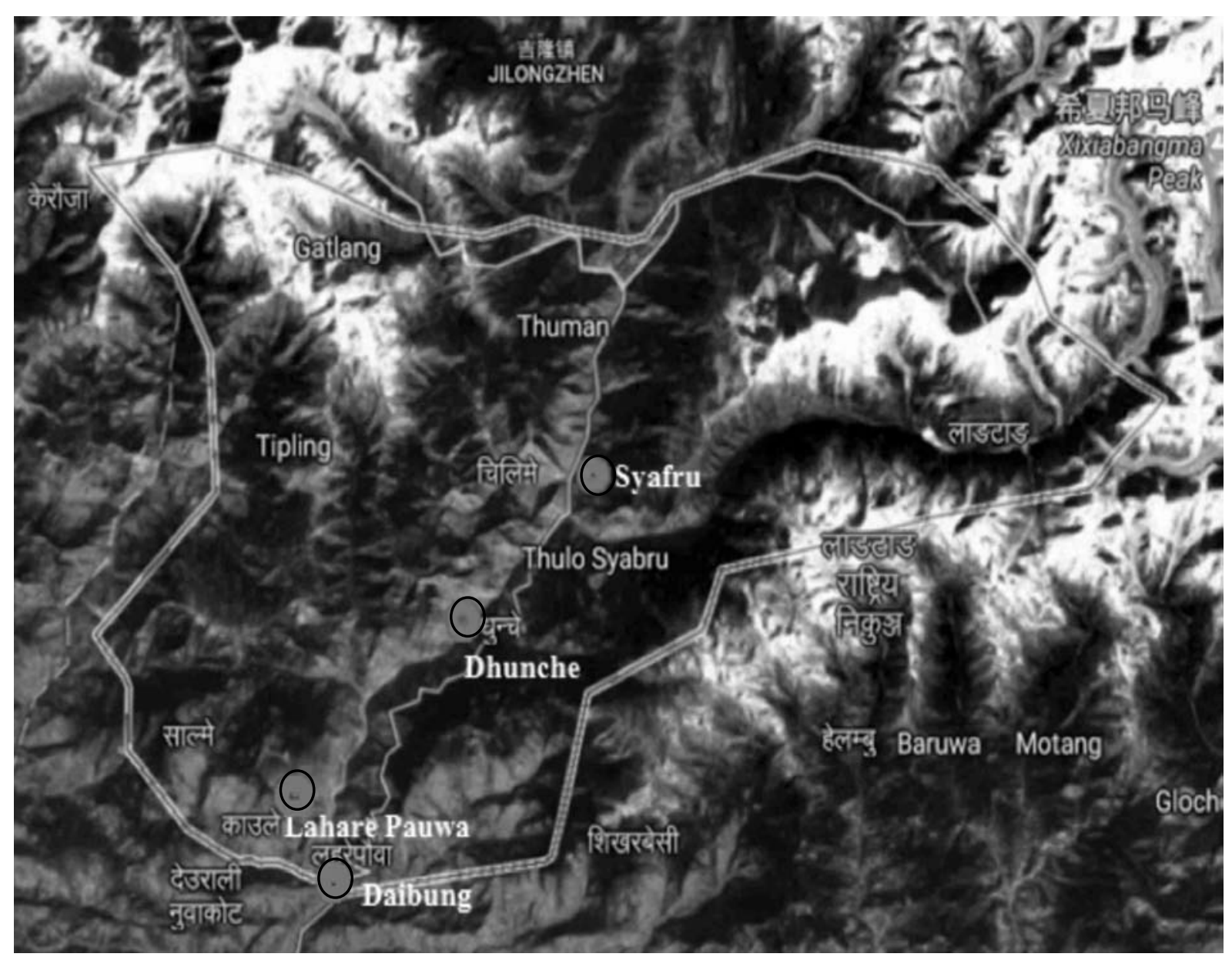

Figure 1 Map of Rasuwa district showing VDCs (Black circle) 
model has been used to examine the factors affecting agricultural adaptation practices and techniques adoption by the agarian households in the study area. The decision to adopt requires that the agarian households recognize local changes in the long term climate such as temperature and rainfall patter ns (Bryan et al., 2013).

In this case, the logit model used as the dependent variable is dichotomous and the distribution functions are bounded between 0 and 1 . The model is based on the cumulative logistic probability function. It uses logistic CDF and is specified as ( $\mathrm{P}$ yndick \& Rubinfeld, 1991):

$\mathrm{P} 1 / \mathrm{i}=\mathrm{F}\left(\alpha+\beta \mathrm{X}_{\mathrm{i}}\right)=\frac{\mathbf{1}}{\mathbf{1}+\boldsymbol{e}^{-\left(\alpha+\beta X_{i}\right)}}=\frac{\boldsymbol{e}^{\left(\alpha+\beta X_{i}\right)}}{\mathbf{1}+\boldsymbol{e}^{\left(\alpha+\beta X_{i}\right)}}$

Where,

$\mathrm{F}=$ cumulative logistic probability function,

$\mathrm{e}=$ base of natural logarithm,

$\mathrm{P}_{1 / 1}=$ probability that the individual makes a certain choice.

$\mathrm{P}_{1 / \mathrm{i}}\left(1+\mathrm{e}^{\alpha+\beta \mathrm{xi}}\right)=\mathrm{e}^{\alpha+\beta \mathrm{xi}}$

$\mathrm{P}_{1 / \mathrm{i}}=\left(1-\mathrm{P}_{1 / \mathrm{i}}\right) * \mathrm{e}^{\alpha+\beta \mathrm{xi}}$

$\mathrm{P}_{1 / i} /\left(1-\mathrm{P}_{1 / i}\right)=\mathrm{e}^{\alpha+\beta \mathrm{xi}}$

$\log _{e}\left(\mathrm{P}_{1 / \mathrm{i}} / \mathrm{P}_{2 / \mathrm{i}}\right)=\mathrm{P}_{1 / \mathrm{i}} /\left(1-\mathrm{P}_{1 / \mathrm{i}}\right)=\alpha+\beta \mathrm{X}_{\mathrm{i}}=\mathrm{Z}_{\mathrm{i}}$

The left-hand side of equation (2) is known as the log odds or the logit transformation and the model is known as the linear logit model. Wigly (1985) has pin-pointed the importance of logit transformation: it increases from - $\infty$ to $+\infty$ as $\mathrm{P}_{1 / i}$ increases from 0 to 1 . Thus, while the probability is bounded, the logit is unbounded with respect to the values of X. According to Wigly, the predicted Logit values are unbounded, but the predicted probability (which can be found by substituting into equation 3 are confined to the $0-1$ range. In this study, $\mathrm{P}_{1 / i}$ represents the probability that individual ' $\mathrm{i}$ ' adopts agricultural adaptation techniques and practices and, 1- $\mathrm{P}_{1 / \mathrm{i}}=\mathrm{P}_{2 / \mathrm{i}}=1 /\left(1+\mathrm{e}^{\left(\alpha+\beta \mathrm{x}_{\mathrm{i}}\right)}\right)$ represents the probability that individual ' $\mathrm{i}$ ’ does not.

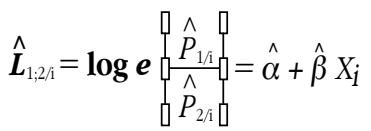

\section{Dependent and explanatory variables}

As the agricultural production system is rain-fed in nature and farmers have perceived threats on household food security due to decreasing amount of rainfall, increased incidence of droughts, even during rainy season, and changes in crop maturity periods, they have adopted strategies to minimize the associated risks. The techniques and practices adopted include cultivating different crops, planting different varieties of crops changing the extent of land put into crop production and using organic manure and biopesticides. If a household has adopted at least one of the above techniques or practices, it is regarded as an adopter and assigned a value of one, zero otherwise.
The analysis of the factors influencing the adoption of various adaptation practices in the mid-hills of Nepal has revealed that perception of rainfall changes, size of landholding, status of land tenure, distance to motor road, access to productive credit, information, extension services, and skill development trainings were influential factors (Piya et al., 2013). Similarly, the result of the logistic regression analysis showed that adaptation practice is significantly influenced by farm size, number of family members available for far ming, farm income, food sufficiency from own farm, and membership in the community level organizations and use of credit. In some cases, subsidies in the technology from the local organizations enhanced the adaptation technology on climate change (Tiwari et al., 2014).

The studies have shown that adaptation does not occur without influence from other factors such as socio-economic, cultural, political, geographical, ecological and institutional that shapes the human-environment interactions (Eriksen et al., 2011). Adaptation to climate change is needed both in the short term and long term basis (Adger et al., 2003; Eriksen et al., 2011; Pittock \& Jones, 2009). The adaptation theory posits that social, economic, ecological and institutional systems as well as individuals can and do adapt to changing environment (Smithers \& Smit, 2009).

The explanatory variables are chosen based on previous studies carried out in Nepal and elsewhere on climate change adaptation in agriculture and data availability. These variables include age, gender, and education of the household head, household size, number of months of food self -sufficiency from their own production, perceived current knowledge and skill on agricultural adaptation, and perception of decreasing amount of rainfall during rainy season. The data was analyzed using STATA statistical package.

\section{Results and Discussion}

Analysis of hydrological and meteorological information The climate data of Rasuwa has been analyzed for the period from 1989 to 2012. It shows that the increase in annual average, maximum and minimum temperature for $1989-2012$ period was $0.02^{\circ} \mathrm{C}, 0.06^{\circ} \mathrm{C}$ and $-0.01^{\circ} \mathrm{C}$, respectively (Fig. 2, Fig. 3). The increase of average minimum temperature was $0.06{ }^{\circ} \mathrm{C}$ in January and $0.04^{\circ} \mathrm{C}$ in July. On the other hand, the maximum temperature increase was $0.03^{\circ} \mathrm{C}$

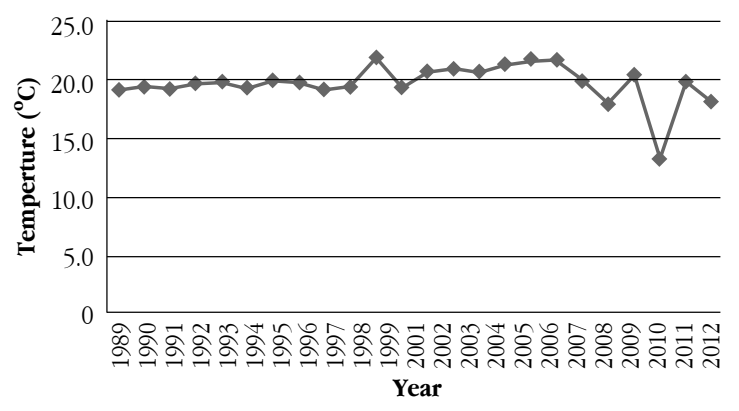

Figure 2 Average annual maximum temperature in Dhunche, Rasuwa district (1989-2012)

\section{喻TU-CDES}




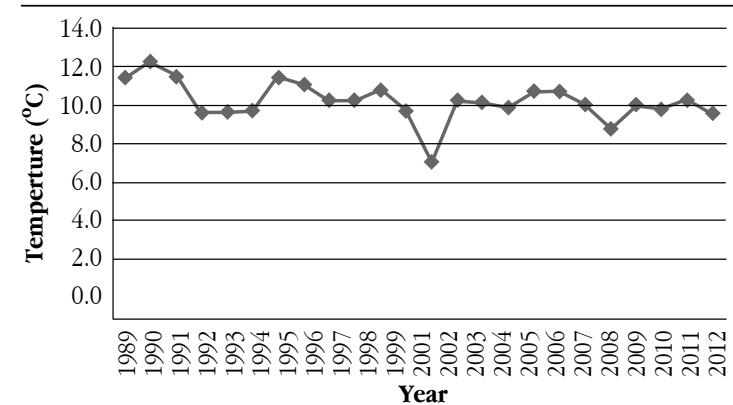

Figure 3 Average annual maximum temperature in Dhunche, Rasuwa district (1989-2012)

in January and $0.08^{\circ} \mathrm{C}$ in July. The average rainfall increase per year for the period was $42 \mathrm{~mm}$. Disaggregating by crop season, there was negative growth $(-0.12 \mathrm{~mm})$ between Januar y and April, an increase of $9.25 \mathrm{~mm}$ during April to June, and $37 \mathrm{~mm}$ during June to September for the period from 1989 to 2012.

\section{Socio-demographic information}

The average age of the household head ranged between 47 and 57 years. It was the highest for the Daibung VDC and lowest for Dhunche VDC (Table 1). The average household size ranged between 4.9 (for Syaphru) and 6.4 (for Daibung). Similarly, the percentage of female headed household was highest for Daibung and lowest for $\mathrm{L}$ aharepauwa. The dependency ratio, which is defined as the ratio of the dependent population (less than 15 years and more than 60 years) to the working age population was the highest in the Daibung VDC (0.92). It means a single working age population has to support equivalent number of other population with regard to supporting livelihood. In other VDCs, it appeared to be around 0.70 .

The educational status of the household head was higher for Daibung and Laharepauwa compared to Syaphru and Dhunche. The main occupation of the household heads was agriculture in the study area. The land is considered to be the principal asset in the rural areas. The average landholding size was at a range of 10 to 17 ropanies ( 1 ropnai = about 0.051 ha.). This was the highest in Syaphru and lowest in Daibung. The households having food self-sufficiency ranged between 5.3 and 7.1 months.
Climate change perception of the agarian households In the study area, $10 \%$ to $30 \%$ of the households were aware about climate change. The households in upper region (Syaphr u and Dhunche) perceived the changes in crop growing and harvesting season more than the households residing in the lower region (Daibung and L aharepauwa), while reverse was the case for shortening of winter period. The households reported that compared to earlier time, the yearly rainfall is not supporting crop production as they perceived decreasing amount of rainfall in both rainy and winter season. The increased incidence of droughts, even during rainy season, was the perception among the households. The insufficient cur rent knowledge about the agricultural adaptation practices were also reported by $20 \%$ to $40 \%$ of the households (Table 2).

The cropping patter $n$ is different in upper and lower areas of Rasuwa. In Syaphru and Dhunche area, the farmer plant potato, maize, millet and oat, while wheat in the lowland. In case of Daibung and Laharepauwa, the cropping patter $n$ in lowland is paddy, maize, wheat and mustard, while maize, millet, vegetables and potato in the upland. Farmers have also changed the crop type in the study villages. Depending on the location, they have changed wheat to potato, maize to millet, wheat to maize and potato to maize.

As reported by the farmers, the harvesting time was delayed by one month in maize and potato, while it was one month earlier in case of wheat in Syaphru. In case of Dhunche, the harvesting time of potato and wheat were delayed by one and half months, while only one month for maize. In Daibung, the harvesting time of wheat was one month earlier, while one month delayed for maize. In Laharepauwa, the harvesting time of maize, wheat and paddy was delayed by one and half months.

\section{Analysis of agricultural adaptation}

The agricultural adaptation techniques and practices include cultivating different crops, planting different varieties of crops, changing the extent of land put into crop production and using organic manure and bio-pesticides. The result of the agricultural households' adoption of these practices and techniques using logit model is presented in T able 3. The Lik elihood Ratio Chi square value was 22.47 implying that the model fits ver y well to the data, that is, the likelihood of the null hypothesis which states that the coefficients are equal to zero being correct is extremely low.

Table 1 Socio-demographic information

\begin{tabular}{lllll}
\hline & \multicolumn{4}{c}{ VDCs } \\
\cline { 2 - 5 } Average Characteristics & Syaphru & Dhunche & Daibung & Laharepauwa \\
\hline Age of the Household head (years) & 51.0 & 47.6 & 56.5 & 50.0 \\
Education of the Household head (category) & Primary & Primary & Secondary & Secondary \\
Female Headed Households (percent) & 16.7 & 33.3 & 36.7 & 13.3 \\
Household Size (no.) & 4.87 & 5.41 & 6.43 & 6.26 \\
Dependency ratio & 0.76 & 0.69 & 0.84 & 0.67 \\
Average Landholding size (ropani) & 16.57 & 12.66 & 10.04 & 13.58 \\
Av. Food self-sufficiency (months) & 5.6 & 6.9 & 5.3 & 7.1 \\
\hline
\end{tabular}


Most of the variables tested had the expected signs. The results indicate that farmers' decisions to adopt agricultural practices are driven by a number of factors. It shows that household size, education level of the household head, number of months food self-sufficiency from own production, and perceived inadequacy of knowledge on climate adaptation in agriculture appeared to be significant at $5 \%$ level.

The number of members in a household was positive and significant variable. This implies that the climate adaptation agricultural practices such as planting demand additional labor which could be met from within the households. With one unit increase in the family member, the probability of adoption would increase by over five percent.

The positive and significant coefficient of the education of the household head implies that the probability of adaptation is greater for those household head having higher educational attainment compared to the less-educated heads. It is obvious that educated farmers have more knowledge, a greater ability to understand and respond to anticipated changes, and have greater access to information and opportunities than others, which might encourage them for adaptation practices. With a unit increase in the level of schooling, the probability of the adoption would increase by about eight percent.

The inadequacy of the current knowledge among the agricultural households was a negative and significant variable affecting climate adaptation in agriculture. The farmers might have perceived this as one of the constraint for adoption. This implies that the probability of adoption of climate adaptation practices would be lower by about $23 \%$ for those households that perceive this as a constraint compared to the households that do not perceive.

The number of months of food self -sufficiency from their own production positively and significantly influenced adaptation decision. For a unit increase in food self -sufficient month, the probability of adoption of climate adaptation practices would rise by four percent. This is indirectly related to land holding size with productive plots which could supply more quantity of food items to household compared to the unproductive plots. The age and gender of the household head variables were negative while perception on decreased amount of rainfall during rainy season was positive on adoption. However, all of them were not significant affecting adoption

Table 2 Perception of households (\%) about climate change

\begin{tabular}{lcccc}
\hline & \multicolumn{4}{c}{ VDCs } \\
\cline { 2 - 5 } Average Characteristics & Syaphru & Dhunche & Daibung & Laharepauwa \\
\hline Hrard about climate change & 17.0 & 30.0 & 10.0 & 20.0 \\
Changes in crop growing and harvesting time & 30.0 & 40.0 & 10.0 & 10.0 \\
The winter is becoming short & 26.7 & 23.3 & 53.3 & 73.3 \\
Decreasing amount of rainfall every year during rainy season & 40.0 & 30.0 & 53.3 & 36.7 \\
Decreasing amount of rainfall every year during winter season & 93.3 & 93.3 & 80.0 & 43.3 \\
The yearly rainfall is not supporting crop production as before & 90.0 & 80.0 & 66.7 & 36.7 \\
There have been increased incidence of droughts & 26.7 & 16.7 & 33.3 & 33.3 \\
during rainy season & & & & 20.0 \\
Inadequacy of current knowledge on agricultural & 40.0 & 36.7 & 20.0 \\
adaptation methods (constraint) & & & & \\
\hline
\end{tabular}

Table 3 Logit model on adaptation of agricultural techniques/practices

\begin{tabular}{lc}
\hline Explanatory Variables & Marginal effects ${ }^{\mathbf{1}}$ coefficients \\
\hline Constant & -0.419 \\
Age of the household head & 0.0055 \\
Household size & $0.0536^{* *}$ \\
Gender of the household head (dummy) & -0.008 \\
Education of the household head (scale) & $0.078^{* *}$ \\
Food self-sufficiency from own production & $0.039^{* *}$ \\
Perceived inadequacy of knowledge on climate adaptation in agriculture & $-0.229^{* *}$ \\
Perception on decreased amount of rainfall during rainy season & 0.241 \\
Pseudo R Square & 0.135 \\
LR Chi-square & 22.47 \\
Prob > Chi-square & 0.0021
\end{tabular}

${ }^{*}$ refers significant at $5 \%$ probability level

${ }^{1}$ Marginal effects refers to the partial derivatives of the expected value with respect to the vector of characteristics. They are computed at the means of the Xs 


\section{Conclusion}

Climate change affects crop and livestock production practices and their yields. Negative effects are projected to be more prominent than the positive effects. The temperature in the study area is increasing and rainfall pattern is also becoming erratic over the years. This has affected the agricultural production, thereby threatening the food security of mountain people.

The average food self-sufficiency, the number of months sustained by own farm production, ranged between five and seven months. The households perceived decreased amount of rainfall during both winter and rainy season which is not supporting crop production as before.

Small proportions of the households were aware of climate change. The farmers have adopted different strategies to cope with the effects of climate change. Some have cultivated different crops, while others have adopted different varieties of crops to shorten the growing season and also used or ganic manure and biopesticides. The adoption of these practices is constrained by inadequate current knowledge on adaptation, among others.

The household size, education level of the household head, number of months of food self -sufficiency, and perceived inadequacy of cur rent knowledge on climate adaptation in agriculture were the main variables significantly affecting climate adaptation in agriculture.

Climate adaptation seems to be the most efficient and friendly way for far mers to neutralize the potential adverse effects. Households perceiving the climate change and its impacts increase the probability of adoption of adaptation measures. Furthermore, the government should implement programs to enhance the adaptive capacity of the far mers. There is a need to document and verify the indigenous knowledge and practices on scientific basis for further replication in the area. The far mers should be made further aware about the effects and should be supported to enhance their knowledge and skills, and to avail the techniques and equipment related to climate change adaptation in agriculture.

\section{References}

Adger, W.N., Huq,S., Brown, K., Conway, D, \& Hulme, M. (2003). Adaptation to climate change in the developing world. Progress in Development Studies,3(3), 179-195.

AfDB. (2003). Poverty and climate change:reducing the vulnerability of the poor through adaptation. In Sperling, F.(ed.), African Development Bank (AfDB).

Bryan, E., Ringler, C., Okoba, B., Roncoli, C., Silvestri, S., \& Herrero, M. (2013). Adapting agriculture to climate change in Kenya: Household strategies and determinants, Journal of Environment Management, 114, 26-35.

CBS.(2014). Population Monograph of Nepal. Central Bureau of Statistics, Nepal.
CBS.(2011). Nepal Living Standard Survey (NLSS-III) 2010/11. Central Bureau of Statistics, Nepal.

Chang, C. (2002). The potential impact of climate change on Taiwan's agriculture. Agricultural Economics, 27, 51-64.

Cline, W. R. (2008). Global warming and agriculture.Retrieved March 2008, Volume 45, Number 1, from http://www.imf.org/external/pubs/ft/fandd/2008/03/cline.htm-

DDC-R. (2002). District perspective plan, District Development Committee, Rasuwa.

Eriksen, S., Aldunce, P., Bahinipati, C.S, Martins, R.D., . Molefe, J.I., Nhemachena, C. Obrien, K., Olorunfemi, F., Park, J. Sygna, L. \& Ulsrud,K. (2011). When not every response to climate change is a good one: Identifying principles for sustainable adaptation. R Climate and Development (Review Article).

Gebreegziabher, Z., Stage, J. Mekonnen, A. and Alemu, A. (2011). Climate Change and the Ethiopian Economy: A Computable General Equilibrium Analysis. Environment for Development (EfD), Discussion Paper Series, October 2011, EfD DP 11-09.

IPCC (2014): Climate Change 2014: Synthesis Report. Contribution of Working Groups I, II and III to the Fifth Assessment Report of the Intergovernmental Panel on Climate Change.R.K. Pachauri and L.A. Meyer (eds.). IPCC, Geneva, Switzerland..

Jenny, A.L. \&. Egal, F.(2002). Household food security and nutrition in mountain areas: an often forgotten story. Nutrition programs service, FAO-ESNP, Rome.

Joshi, B. (2009). Impact of climate change on agricultural production in Rasuwa district of Nepal. (Unpublished M. Sc. Thesis). College of Applied Sciences, Tribhuvan University.

Khanal, N.R. (2005). Water induced disasters: Case studies from the Nepal Himalayas. In Herrmann, A. (Ed.) . Proceedings of International Conference on Hydrology of Mountain Environments, Berchtesgaden, Germany, 27 Sept-1 Oct 2004. pp. $179-188$.

Kimball, B. A. (1983). Carbon dioxide and agricultural yield: An assemblage and analysis of 430 prior observations, Agronomy Journal, 75, 779-786.

Mahtab, F.U. (1992). The delta regions and global waming: impact and response strategies for Bangladesh. In Schmandt, J. and J. Clarkson (Eds.), The regions and global warming: impacts and response strategies. [, Oxford University Press, New York.

MoE. (2010). National adaptation program of action to climate change. Ministry of Environment, Kathmandu, Nepal.

Norris, P. E., \& Batie, S. S. (1987). Virgina farmers' soil conservation decisions: An application of Tobit analysis. Southern Journal of Agricultural Economics, 19,79-90.

Pachauri, R. K. (1992). Global warming: impacts and implications for South Asia. In Schmandt, J. \&. Clarkson, J. (Eds.). The Regions and Global Warming: Impacts and Response Strategies. Oxford University Press, New York.

Pindyck, R. S., \& Rubinfeld, D.L. (1991). Econometric models and economic forecasts. New York, McGraw-Hill. 
Pittock, B. A., \& Jones, N. R. (2009). Adaptation to what and why? In L. E. Schipper \& Burton, I. (Eds.), Adaptation to Climate Change. Earthscan London.

Piya, L., Maharjan, K.L. \& Joshi, N.P. (2013). Determinants of adaptation practices to climate change by Chepang households in the rural Mid-Hills of Nepal. Regional Environmental Change, 13(2), 437-447.

Practical Action Nepal. (2009). Temporal and spatial variability of climate change over Nepal (1976 - 2005). Practical Action, Katmandu Office.

Reilly J., Tubiello, F., McCarl, B. \& Melillo, J. (2001). Climate change and agriculture in the United States. In National Assessment Synthesis Team, Climate Change Impacts in the United States: The Potential Consequences of Climate Variability and Change,Report for the US Global Change Research Program, Chapter 13, Cambridge University Press. .

Rosenzweig, C. \& Hillel, D. (1998). Climate Change and the Global Harvest: Potential Impacts on the GreenhouseEffect on Agriculture, Oxford University Press, New York.
Smithers, J., \& Smit, B. (2009). Human adaptation to climatic variability and change. In Schipper, L.E \& Burton, I. (Eds.). Adaptation to Climate Change Earthscan London.

Swaminathan, M.S. (2002). Climate change, food security and sustainable agriculture: Impacts and adaptation strategies. In Shukla, P.R., Sharma, S.K. \& Venkata Raman, P. (Eds.), Climate change and India: Issues, concerns and opportunities Tata McGraw-Hill Publishing Companay Ltd, New Delhi. .

Tesso, G., Emana, B. \& Ketema, M. (2012). Econometric analysis of local level perception, adaptation and coping strategies to climate change induced shocks in North Shewa, Ethiopia. International Research Journal of Agricultural Science and Soil Science, 2(8),347-363.

Tiwari, K.R., Rayamajhi, S., Pokharel, R.K. \& Balla, M.K. (2014). Determinants of the climate change adaptation in rural farming in Nepal Himalaya. International Journal of Multidisciplinary and Current Research, 2:234-240.

Wigly, N. (1985). Categorical Data Analysis for Geographers and Environmental Scientists. Longman: New York, USA. 